\title{
Leading Responsibly: Relevance of the Major Leadership Theories in the Caribbean Context
}

\author{
S. Aqeel Tirmizi \\ Antioch University \\ Ken Williams \\ SIT Graduate Institute \\ S. Noor Tirmizi \\ Daira Ltd.
}

We examined the relevance of several leadership approaches in the Caribbean region to inform the current leadership practice in a number of sectoral domains (e.g. private, public, NGO). Using primarily a quantitative survey approach, we studied the relevance of transformational, transactional, authoritative, adaptive, servant, values-based, and spiritual leadership styles. Specifically, we explored each of the major leadership style's application to the organizational (private, public and NGOs), political, religious, community and grassroots settings. The findings indicate a strong relevance of transformational leadership across a variety of work contexts in the Caribbean region with mixed and more nuanced results for other styles.

Keywords: Leadership Theories, Caribbean Leadership, Leadership Styles, Adaptive Leadership, Transformational Leadership, Spiritual Leadership, Servant Leadership, Values-Based Leadership, Transactional Leadership, Authoritative Leadership, Cross-cultural leadership

\section{INTRODUCTION}

Over the last thirty years, the world has become more "globalized", surfacing economic challenges, social divisions, and governance complexities. In this environment, the aspirations for responsible, inclusive, and just leadership are on the rise. However, communities, countries, and regions across the world are facing numerous leadership challenges and dilemmas. While our pursuit to build new leadership theory and practice should continue, we must also examine the relevance of existing leadership knowledge we have accumulated over the last few decades. However, we don't have enough empirical evidence to determine the suitability of these theories across a variety of contexts including the Caribbean region.

While some research endeavors indeed examined the relevance of selected leadership styles in the Caribbean context, these efforts have been limited. For instance, Flemming (2016) examined the 
relationship of transformational leadership, organizational culture, and performance in public sector organizations in the Virgin Islands. Caesar (2013) in exploring the relevance of prevalent leadership theories to the Caribbean context noted, "Besides there is a great deal of uncertainty over which theory is suitable due to lack of empirical evidence. Herein lies some of the weaknesses, and basis for cautious implementation of leadership models in varied school contexts and landscapes" (p. 120). Other recent research echoes the sentiments about the paucity of research on leadership approaches as applicable to developing countries like the Caribbean Islands (Lituchy, Ford, \& Punnett, 2013; Marshall, 2015a; Smith, Francis \& Harper, 2015).

There is not a dominant leadership definition that exists among leadership scholarship; however, several definitions identify some common themes which include an influence process to attain a shared goal (Rost,1993; Shamir, House \& Arthur., 1993) and the voluntary receiving of this influence (Jago, 1982; Kotter, 1988). Paglis and Green., (2002) suggested a definition of leadership that seems to include the various themes common across many leadership definitions:

Leadership is a process of diagnosing where the work group is now and where it needs to be in the future and formulating a strategy for getting there. Leadership also involves implementing change through developing a base of influence with followers, motivating them to commit to and work hard in pursuit of change goals, and working with them to overcome obstacles to change (Paglis \& Green, 2002, p. 217).

Lituchy et al. (2013) critique this definition as elevating elements of leadership that are important in the West, a common concern of current leadership definitions. These elements include, future orientation, a strategic approach, valuing change, influencing, commitment and hard work towards achieving goals. Many of these elements are not as valued in an African context and, as the Caribbean peoples are predominantly from African descent, these elements may not be as relevant nor applicable in a Caribbean context.

Several scholars studying leadership/management in Africa and the diaspora, have noted the importance of contextualization of issues and the need to examine the relevance of western models of leadership being studied and applied in countries of the diaspora (James, 2008; Beugre \& Offodile, 2001; McFarlin, Coster, \& Mogale-Pretorius, 1999; Lituchy et al., 2013). These scholars noted that some leadership behaviors that are ineffective in Western countries' contexts, might be effective in countries of the diaspora, including the Caribbean. Some of the elements of leadership that were considered as important in Africa and the diaspora, included spirituality, time as eternal, ancestral connections, strong relationships, and communalism, with decisions being holistic and collective (Smith, 2003). According to Lituchy et al., (2013), several studies show the importance of the powerful, hierarchal leader who is communal and a servant leader, and according to them, cultural context is one of the strongest aspects of leadership. The Caribbean comprises of very small islands, with fragile economies and very limited resources, with a history that fostered a dependence syndrome among natives, whose descendants are now the leaders.

It is in this spirit we decided to empirically examine the relevance of selected leadership theories in the Caribbean context. The focus of this research is predominantly on the Caribbean islands that were once former British colonies, and where English is the main language spoken. Although these three islands might have many similarities such as religion or connections to a common colonial past, there are also distinct patterns of behavior and customs of the peoples of these islands which makes each of them unique (Punnett \& Greenidge, 2009). The overwhelming majority of the peoples populating Caribbean islands are of African descent and this descent has strong influence on leadership and followership practices. Although Christianity has survived as the major religion, African practices and beliefs have been infused into Christian practices in the Caribbean (Punnett \& Greenidge, 2009).

Among other works, a good amount of research and writing is now available on transformational, authoritative, adaptive, servant, transactional, values-based, and spiritual leadership. These research streams also seem relevant in the Caribbean region as noted above. Thus, we decided to focus on these 
theories in our current study reported in this paper. Specifically, we explore the following question in this study:

What leadership style (s) are most relevant to practice effective leadership in the organizational, community, political, and religious settings in the Caribbean region?

A quantitative survey design was used in this study and a total of 102 respondents participated in it from the Caribbean region. The survey was conducted in Barbados, Jamaica, Trinidad \& Tobago. In the section below, we introduce and summarize the key leadership styles and the leadership literature that anchors them. The purpose of this review is not to offer a thorough description of the individual leadership approaches as this is beyond the scope of our paper. Our intention here is to provide a brief overview of the relevant leadership styles. Following this overview of leadership approaches, we describe the study findings and results. For the purposes of this study we are using the terms leadership theories, leadership styles and leadership approaches interchangeably.

\section{OVERVIEW OF LEADERSHIP STYLES}

As noted above, the major focus of the study is on examining the relevance and application of transformational, authoritative, adaptive, servant, transactional, values-based, and spiritual leadership approaches in the Caribbean context considering the current and emerging dilemmas and challenges the region faces. In order to guide our understanding of these leadership styles and inform our methodology, we drew upon a number of relevant works in the existing leadership literature. In the section below, we summarize the literature-based thinking related to the focal leadership styles, which formed the foundation of our study.

\section{Transformational Leadership}

Transformational leadership is concerned with emotions, values, ethics, standards, and long-term goals. Bass \& Steidlmeier (1999) state that transformational leadership fosters autonomy, creates challenging work, and is important for followers' job satisfaction (p. 10). This type of leadership moves the follower beyond self-interests and elevates the followers' level of maturity "and ideals as well as concerns for achievement, self-actualization, and the well-being of others" (Bass \& Steidlmeier, 1999, p. 11).

In a study in the Caribbean examining the relationship between transformational leadership and organizational performance using transformational leadership and the competing values framework, Flemming (2016) found positive correlations between transformational leadership and organizational performance. This study found that the transformational leadership components of idealized influence, inspirational motivation, and individualized consideration had strong positive correlations with the clan and adhocracy aspects of the competing values framework compared to the market and hierarchical culture types of the competing values framework (Flemming, 2016). This has implications for the Caribbean which is considered low on hierarchy and power distance (Lituchy et al., 2013).

\section{Authoritative (Hierarchical) Leadership}

In this type of leadership, authority is drawn from traditional sources, such as tribe or class, or organizational sources, such as position and rules. According to Dinham \& Scott, (2008) authoritative leaders are "responsive, warm, and supportive. They are sensitive to a diversity of individual and collective needs and are inclusive" (p. 20). While they are sensitive to the needs of their followers, they may also set high standards and be demanding of their followers.

In authoritative leadership, there is a clear chain of command and authority is legitimized by a formal system of rules or laws. The standard of success is made known, as well as the rewards (Goleman, 2000, p. 84). Dinham \& Scott, (2008) describe that authoritative leaders "are clear in their expectations of themselves and staff" (p. 21) and followers know where they stand with their leader. Sternberg (2013), while noting relevance of the authoritative leadership model, acknowledges that there is a time and a place for all styles of leadership.

Journal of Leadership, Accountability and Ethics Vol. 16(4) 2019113 


\section{Adaptive Leadership}

Adaptive leadership is a type of social leadership which helps solve complex problems and challenges. Glover, Friedman, \& Gordon., (2002) describe adaptation as the "process by which leaders continuously both assimilate information from the context of the world and then accommodate their organizations to specific contexts in which they are embedded" (p. 17). They go on to state that "adaptive leadership is based on being open to the changes going on around us and then making effective decisions with these changes, including implementing these in appropriate ways" (p. 17).

Adaptive leaders do not rely on traditional authority but employ processes that encourage and enable change. According to Heifetz \& Laurie, (1997) adaptive leaders ask tough questions and help draw issues out (p. 125). Adaptive leaders learn from the environment which they work in. They can identify the adaptive challenges their organizations face when implementing change and how to overcome them. They also know how to navigate the environment they work in.

\section{Servant Leadership}

In Servant Leadership, one attains the position of leader through acting as a servant to others. In citing Greenleaf, Carroll (2005), describes that servant leadership starts with an inclination towards service and is followed by a conscious choice to lead. The leader's desire is to make sure the followers' needs are met and served. Jit, Sharma \& Kawartra (2016) found that servant leaders, "adopt a more humane approach toward conflict resolution", and that servant leaders try to find mutually beneficial solutions and involve the employees in the process when resolving conflict with subordinates (p. 605). Pekerti (2010) found a positive correlation between servant leadership and employees' feelings of trust for that leader ( $\mathrm{p}$. 654).

A study by Hirschy (2008) found that servant leaders exhibited agapao love, demonstrated humility, conveyed altruism, act as visionaries, developed trust, empowered, and served their followers in the Jamaican context. This study was limited to a very small sample but indicates that servant leadership might be relevant within the Caribbean context, as Hirschy concludes, the servant leadership model is "acceptable, valid, and being used within the Jamaican culture." (Hirschy, p. 21).

\section{Transactional Leadership}

Transactional leadership focuses on the exchanges that occur between leaders and their followers. This type of leadership is based on the assumptions that people are motivated by rewards and punishments and that systems work best with a clear chain of command. Groves \& LaRocca (2011) describe that transactional leaders "influence followers by controlling their behaviors and rewarding agreed-upon behaviors" (p. 512). The transactional leader creates set structures and systems that make it clear to subordinates what is required of them and the rewards they will get for succeeding. While transactional leadership can be effective, it does not create a strong emotional attachment between the followers and the leader.

Carrison (2016) argues that transactional leadership, with its values of fair trade and clear expectations, helps employees manage their time better and promotes a more easily achievable work-life balance in those being led (p. 6). Transactional leadership is better suited to stable work conditions, during which there exist no impending crises for the organization (Popper \& Zakkai, 1994). Whittington, Coker, Goodwin, Ickes \& Murray (2009) stress, "that the terms and conditions of transactional leadership must be clearly communicated and agreed upon for this style of leadership to be effective" (p. 1875).

\section{Values-based Leadership}

A lot of work on leadership today is considered values-driven. Values-driven means that a leader's work is grounded in overall meta-values such as equality, justice, and fairness. In a review of the literature, Russell (2001) found that the values of honesty and integrity seemed the most essential values for good leaders, but other values he listed include concern for others, fairness, and justice (p. 79). Fernández \& Hogan (2002) state that values are important because they "explain the focus and direction of people's actions" (p. 25). 
While this type of leadership emphasizes its message using one's/organization's values to guide decisions and processes, values are implicitly or explicitly linked to a larger context and higher purpose with a sense of morality. Prilleltensky (2000) describes that values "guide the process of working toward a desired state of affairs" (p. 144). According to Fernández \& Hogan (2002) a successful values-based leader acts in "accordance with the values that are also endorsed by the group" (p. 27) they are leading.

\section{Spiritual Leadership}

Spiritual leadership involves the integration of body, mind, heart, and spirit. It brings about a sense of calling and meaning in work and encourages an altruistic culture of love where leaders and followers have genuine care, concern, and appreciation for self and others. According to Jamaludin, Rahman, Makhbul \& Idris (2011), a spiritual leader ensures that the "spiritual needs of the workers are fulfilled in order to enhance their work quality and productivity" (p. 78). Spiritual leaders are not just interested in the economic rewards from their follower's hard work but are interested in their follower's spiritual satisfaction (Jamaludin et al., 2011).

In the LEAD research project that examined leadership effectiveness in Africa and the African Diaspora (Lituchy, Galperin \& Punnett, 2017), it was noted that the Caribbean countries in this study identified spiritual leadership as important. Religion was considered as an important factor in leadership in the Caribbean context with Christianity being classified as a critical factor in leadership in Barbados, while in Trinidad and Tobago, Christianity and Hinduism were important factors for leadership. Obeah practices, which are associated with minority religions in the Caribbean, have infiltrated the major religions in the Caribbean, including Christianity (Paton, 2009). An exploratory study by Lituchy et al., (2013) confirmed the importance of spirituality to leadership effectiveness in the Caribbean. Smith et al., (2015), noted the importance of spiritual values in undergirding transformation leadership in the education sector in the Caribbean.

We drew upon the above conceptualizations of the selected leadership theories to inform our examination of their relevance in the Caribbean context. Specific details of how we approached our study are provided in the methodology section below.

\section{RESEARCH METHODOLOGY}

Our methodology comprised a quantitative survey of individuals representing different work contexts in the Caribbean region. The survey was administered to over 150 individuals and 102 respondents completed the survey. The survey was administered in collaboration with in-country research assistants using SurveyMonkey. The survey described the purpose of the study, provided descriptions of the major leadership approaches (e.g. transformational, adaptive, spiritual) and then asked the respondents to rate the relevance of the approaches to specific work contexts or work domains namely private (for-profit), nonprofit, public, political, community, and religious. The survey also provided space for some qualitative input throughout the various sections and collected demographic and background organizational information from the respondents.

The survey countries included Barbados, Jamaica, Trinidad, and Tobago. The education background of respondents ranged from high school diploma to post graduate degrees holders and their age ranged between $20 \mathrm{~s}$ and $60 \mathrm{~s}$. About $40 \%$ respondents were between the ages of 30 and 40 years. In terms of gender, females comprised $48 \%$ and males were $52 \%$ of the respondent pool. In order to understand the intervening effects of respondents' background, we particularly focused on two factors. The first was the primary work sector (public, private, and NGO/nonprofit) they were working in and the second was their gender. In the results and findings section below, we show the alignment between these factors and the responses. The main analytical procedure for our study was cross tabulations. 


\section{RESULTS AND FINDINGS}

The study results are presented in the Tables 1 to 9 below. Tables 1 to 7 include responses for the seven leadership styles and the six contexts or domains of work which was the focus of the study. The data in these tables is further broken down and organized to show respondents' background and the primary sector they belong to namely private, public, and $\mathrm{NGO}$ /nonprofit. Tables 8 and 9 show the results for the relevance of the seven leadership styles and six work domains based on the respondents' gender. Our results demonstrated a strong relevance of transformational leadership to all the work contexts in the Caribbean region within the for-profit, public, and non-governmental sectors. While other leadership styles also seemed relevant, the results were mixed in some cases. For instance, authoritative, servant, and transactional leadership styles were not seen as relevant across all the work sectors. We believe that the findings of this research provide timely insights about the relevance of established leadership theory in the Caribbean context. This research supports some of the earlier findings with regards to transformational leadership in the Caribbean with education and other sectors. For instance, Marshall (2015b) found that the transformational leadership style moderated the level of stress experienced by primary and secondary school teachers in Barbados.

\section{TABLE 1}

\section{RELEVANCE OF TRANSFORMATIONAL LEADERSHIP}

\begin{tabular}{|l|l|l|l|l|l|l|l|c|}
\hline & \multicolumn{2}{|l|}{$\begin{array}{l}\text { Private Sector } \\
\text { Respondents }\end{array}$} & \multicolumn{2}{l|}{$\begin{array}{l}\text { Public Sector } \\
\text { Respondents }\end{array}$} & \multicolumn{2}{l|}{$\begin{array}{l}\text { NGO/Other Sector } \\
\text { Respondents }\end{array}$} & \multicolumn{2}{|l|}{ Total } \\
\hline \multirow{2}{*}{$\begin{array}{l}\text { Leadership } \\
\text { within }\end{array}$} & \multicolumn{2}{|c|}{ Relevance } & \multicolumn{2}{|c|}{ Relevance } & \multicolumn{2}{c|}{ Relevance } & \multicolumn{2}{c|}{ Relevance } \\
\cline { 2 - 9 } & Less & More & Less & More & Less & More & Less & More \\
\hline Political Context & 15.6 & 84.4 & 35.5 & 64.5 & 8.3 & 91.7 & 20 & 80 \\
\hline Public Context & 28.9 & 71.1 & 29.0 & 71.0 & 29.2 & 71.0 & 29 & 71 \\
\hline Private Context & 20.0 & 80.0 & 22.6 & 77.4 & 21.0 & 79.0 & 21 & 79 \\
\hline NGO Context & 28.9 & 71.1 & 12.9 & 87.1 & 12.5 & 87.5 & 20 & 80 \\
\hline Religious Context & 13.3 & 86.7 & 9.7 & 90.3 & 16.7 & 83.3 & 13 & 87 \\
\hline Grassroot Context & 22.2 & 77.8 & 9.7 & 90.3 & 12.5 & 87.5 & 16 & 84 \\
\hline
\end{tabular}

As showed in Table 1, transformational leadership appears to be highly relevant across the six work contexts according to respondents from multiple sectors. When we look at the combined responses, transformational leadership is seen as more relevant by about 80 to $90 \%$ of respondents of all the leadership contexts except the public arena. Interestingly, it is among the public sector respondents that we see some notable variance about transformational leadership. About $35 \%$ of them see it as less relevant for the political context, the context they seem to be most familiar with. Respondents from the private and nongovernmental sectors see a higher relevance for transformational leadership and the political context.

Marshall (2015b) found that primary and secondary school teachers had more stress when principals adopted a more autocratic style of leadership. Although this study did not focus on stress it validated that transformational leadership is valued by a large percentage of nationals within the Caribbean countries of Barbados, Jamaica, and Trinidad and Tobago. Marshall (2015b) also showed that there is a need for a variety of leadership styles within the education sector for principals to be successful. This might be one of the factors that is showing up in the data since some of the participants in this current study were from public schools. Lituchy et al., (2013), in a study of leadership in Uganda, Barbados, and Canada, found that inspiration/charisma was rated as one of the most significant attributes that contribute to effective leadership in Barbados and Canada. Inspiration is an important element that corresponds to transformational leadership, lending further validity of the importance of transformational leadership to the Caribbean context. 
TABLE 2

RELEVANCE OF AUTHORITATIVE LEADERSHIP

\begin{tabular}{|l|l|l|l|l|l|l|l|l|}
\hline & \multicolumn{2}{|l|}{$\begin{array}{l}\text { Private Sector } \\
\text { Respondents }\end{array}$} & \multicolumn{2}{l|}{$\begin{array}{l}\text { Public Sector } \\
\text { Respondents }\end{array}$} & \multicolumn{2}{l|}{$\begin{array}{l}\text { NGO/Other Sector } \\
\text { Respondents }\end{array}$} & \multicolumn{2}{l|}{ Total } \\
\hline \multirow{2}{*}{$\begin{array}{l}\text { Leadership } \\
\text { within }\end{array}$} & Relevance & Relevance & \multicolumn{2}{l|}{ Relevance } & \multicolumn{2}{l|}{ Relevance } \\
\cline { 2 - 9 } & Less & More & Less & More & Less & More & Less & More \\
\hline Political Context & 26.7 & 73.3 & 29.0 & 71.0 & 29.2 & 70.8 & 28 & 72 \\
\hline Public Context & 26.7 & 73.3 & 32.3 & 67.7 & 33.3 & 66.7 & 30 & 70 \\
\hline Private Context & 44.4 & 55.6 & 32.3 & 67.7 & 45.8 & 54.2 & 41 & 59 \\
\hline NGO Context & 60.0 & 40.0 & 48.4 & 51.6 & 45.8 & 54.2 & 53 & 47 \\
\hline Religious Context & 44.4 & 55.6 & 51.6 & 48.4 & 54.2 & 45.8 & 49 & 51 \\
\hline Grassroot Context & 62.6 & 37.8 & 64.5 & 35.5 & 66.7 & 33.3 & 64 & 36 \\
\hline
\end{tabular}

Table 2 shows the results for the relevance of authoritative leadership. The first pattern that stands out here is that the majority of respondents across the three sectors saw authoritative leadership as more relevant for the political and public work contexts. Also, the majority of respondents felt authoritative leadership was less relevant for the community and grassroots settings. The data also suggests that respondents were also somewhat split in terms of authoritative leadership's relevance for the private, nonprofit and religious work domains. Private sector respondents felt that authoritative leadership was overall less relevant for the nonprofit context.

Although Marshall (2015a) reported a significant relationship between leadership style and teacher commitment, the correlations were low which indicated that other factors were important in determining effective leadership. One interpretation is that non values-based styles such as authoritative leadership and transactional approaches has a place in Caribbean leadership.

Public sector respondents saw the high level of relevance of adaptive leadership to the political context and public context. It is not surprising since this group of respondents understands the urgent need for reforms and changes. This pattern of responses also offers optimism. Generally speaking, public sector and political sectors are seen as contexts not open to change. These findings challenge that view and suggest that there might be more openness to adaptive leadership (that invites change and assumes flexibility) than typically believed about the public and political sector.

These results might also reflect participants' views on governments as corrupt institutions and the urgent need for change. Trinidad and Tobago along with Jamaica are considered some of the most corrupt countries in the Caribbean (Transparency International Corruption Index, 2018). While Barbados has the lowest corruption index score in the Caribbean, its citizens see its government institutions as corrupt. This perception was expressed in the 2018 general elections in Barbados, where the incumbent government lost every seat, and the losses were attributed to the government's corruption among other factors (Economist, 2018). 
TABLE 3

RELEVANCE OF ADAPTIVE LEADERSHIP

\begin{tabular}{|l|l|l|l|l|l|l|l|l|}
\hline & \multicolumn{2}{|l|}{$\begin{array}{l}\text { Private Sector } \\
\text { Respondents }\end{array}$} & \multicolumn{2}{l|}{$\begin{array}{l}\text { Public Sector } \\
\text { Respondents }\end{array}$} & $\begin{array}{l}\text { NGO/Other } \\
\text { Sector } \\
\text { Respondents }\end{array}$ & Total \\
\hline $\begin{array}{c}\text { Leadership } \\
\text { within }\end{array}$ & Relevance & \multicolumn{2}{l|}{ Relevance } & \multicolumn{2}{l|}{ Relevance } & \multicolumn{2}{l|}{ Relevance } \\
\cline { 2 - 9 } & Less & More & Less & More & Less & More & Less & More \\
\hline Political Context & 31.5 & 68.5 & 16.1 & 83.9 & 20.8 & 79.2 & 24 & 76 \\
\hline Public Context & 31.1 & 68.9 & 12.9 & 87.1 & 25.0 & 75.0 & 24 & 76 \\
\hline Private Context & 17.8 & 82.2 & 16.1 & 83.9 & 12.5 & 87.5 & 16 & 84 \\
\hline NGO Context & 15.6 & 84.4 & 12.9 & 87.6 & 16.7 & 83.3 & 15 & 85 \\
\hline Religious Context & 35.6 & 64.4 & 25.8 & 74.2 & 37.5 & 62.5 & 33 & 67 \\
\hline Grassroot Context & 26.7 & 73.3 & 6.5 & 93.3 & 25.0 & 75.0 & 20 & 80 \\
\hline
\end{tabular}

Another data point that deserves some attention is the response set from the private sector respondents. They saw a relatively stronger relevance for the adaptive leadership in the private and nonprofit work domains as compared to the political and public work arenas. In general, the majority of the respondents saw adaptive leadership as more irrelevant to all the work contexts.

\section{TABLE 4}

\section{RELEVANCE OF SERVANT LEADERSHIP}

\begin{tabular}{|l|c|c|c|c|c|c|c|c|}
\hline & \multicolumn{2}{|c|}{$\begin{array}{c}\text { Private Sector } \\
\text { Respondents }\end{array}$} & \multicolumn{2}{c|}{$\begin{array}{c}\text { Public Sector } \\
\text { Respondents }\end{array}$} & \multicolumn{2}{c|}{$\begin{array}{c}\text { NGO/Other } \\
\text { Sector Respondents }\end{array}$} & \multicolumn{2}{|c|}{ Total } \\
\hline \multirow{2}{*}{$\begin{array}{c}\text { Leadership } \\
\text { within }\end{array}$} & \multicolumn{2}{|c|}{ Relevance } & \multicolumn{2}{c|}{ Relevance } & \multicolumn{2}{c|}{ Relevance } & \multicolumn{2}{c|}{ Relevance } \\
\cline { 2 - 9 } & Less & More & Less & More & Less & More & Less & More \\
\hline Political Context & 37.8 & 62.2 & 41.9 & 58.1 & 25.0 & 75.0 & 36 & 64 \\
\hline Public Context & 44.4 & 55.6 & 41.9 & 58.1 & 37.5 & 62.5 & 42 & 58 \\
\hline Private Context & 60.0 & 40.0 & 48.4 & 51.6 & 50.0 & 50.0 & 54 & 46 \\
\hline NGO Context & 35.6 & 64.4 & 29.0 & 71.0 & 29.2 & 70.8 & 32 & 68 \\
\hline Religious Context & 22.2 & 77.8 & 12.9 & 87.1 & 29.2 & 70.8 & 21 & 79 \\
\hline Grassroot Context & 33.3 & 66.7 & 16.1 & 83.9 & 45.8 & 54.2 & 31 & 69 \\
\hline
\end{tabular}

Table 4 summarizes the results for servant leadership. While the majority of the respondents indicated that servant leadership is relevant to the majority of the work of domains, there were variations in the response strength. One clear exception to this pattern was from the private sector respondents. The majority of them felt servant leadership was less relevant to the private work context. In fact, respondents from the public and nongovernmental sectors were also split on the relevance of servant leadership to the private sector context. This perspective is understandable as servant leadership is considered to be incompatible to a working environment where competition and efficiency are dominant (Northouse, 2019). As indicated in the total column of table 4, the majority of respondents felt servant leadership was less relevant to the private sector. Servant leadership was seen as more relevant to the religious work context by most respondents but particularly the ones in the public sector. A surprising result was that the $\mathrm{NGO}$ /nonprofit sector respondents were somewhat split about the relevance of servant leadership to community and grassroots level work domain. Opinions were also somewhat divided about the relevance of servant leadership for the public sector. This result might reflect participants' ambivalent perceptions about servant leadership as a viable approach where there is a need for an achievement orientation especially when one considers the weak state of Caribbean economies. 
TABLE 5

RELEVANCE OF TRANSACTIONAL LEADERSHIP

\begin{tabular}{|l|l|l|l|r|r|r|r|r|}
\hline & \multicolumn{2}{|l|}{$\begin{array}{l}\text { Private Sector } \\
\text { Respondents }\end{array}$} & \multicolumn{2}{l|}{$\begin{array}{l}\text { Public Sector } \\
\text { Respondents }\end{array}$} & \multicolumn{2}{l|}{$\begin{array}{l}\text { NGO/Other Sector } \\
\text { Respondents }\end{array}$} & \multicolumn{2}{l|}{ Total } \\
\hline \multirow{2}{*}{ Leadership within } & Relevance & \multicolumn{2}{l|l}{ Relevance } & \multicolumn{2}{l|}{ Relevance } & \multicolumn{2}{l|}{ Relevance } \\
\cline { 2 - 9 } & Less & More & Less & \multicolumn{1}{l|}{ More } & Less & \multicolumn{1}{l|}{ More } & Less & More \\
\hline Political Context & 57.8 & 42.2 & 45.2 & 54.8 & 41.7 & 58.3 & 50 & 50 \\
\hline Public Context & 42.2 & 57.8 & 38.7 & 61.3 & 54.2 & 45.8 & 44 & 56 \\
\hline Private Context & 33.3 & 66.7 & 25.8 & 74.2 & 45.8 & 54.2 & 34 & 66 \\
\hline Nonprofit Context & 62.2 & 37.8 & 64.5 & 35.5 & 70.8 & 29.2 & 65 & 35 \\
\hline Religious Context & 66.7 & 33.3 & 83.9 & 16.1 & 75.0 & 25.0 & 74 & 26 \\
\hline Grassroots Context & 77.8 & 22.2 & 80.6 & 19.4 & 62.5 & 37.5 & 75 & 25 \\
\hline
\end{tabular}

Table 5 shows how the respondents saw the relevance of transactional leadership across the different work domains. The respondents from three sectors were somewhat divided in their views about the relevance of transactional leadership for the political and public work domains. The majority of the respondents across the three sectors felt that transactional leadership was less relevant for the nonprofit religious and community/grassroots work arenas. It is significant to note that transactional leadership was seen as more relevant to the private sector work domain by respondents across all of the three sectors. This finding may be explained in terms of people's perception of the private sector and its primary motivation towards profit-making. That orientation in turn leads to the expectation that there should exist reciprocal arrangement among private sector organizations for those who work in them.

TABLE 6

RELEVANCE OF VALUES-BASED LEADERSHIP

\begin{tabular}{|c|c|c|c|c|c|c|c|c|}
\hline & \multicolumn{2}{|c|}{$\begin{array}{l}\text { Private Sector } \\
\text { Respondents }\end{array}$} & \multicolumn{2}{|c|}{$\begin{array}{l}\text { Public Sector } \\
\text { Respondents }\end{array}$} & \multicolumn{2}{|c|}{$\begin{array}{l}\text { NGO/Other } \\
\text { Sector } \\
\text { Respondents }\end{array}$} & \multicolumn{2}{|c|}{ Total } \\
\hline \multirow{2}{*}{$\begin{array}{l}\text { Leadership } \\
\text { within }\end{array}$} & \multicolumn{2}{|c|}{ Relevance } & \multicolumn{2}{|c|}{ Relevance } & \multicolumn{2}{|c|}{ Relevance } & \multicolumn{2}{|c|}{ Relevance } \\
\hline & Less & More & Less & More & Less & More & Less & More \\
\hline Political Context & 24.4 & 75.6 & 25.8 & 74.2 & 20.8 & 79.2 & 24 & 76 \\
\hline Public Context & 22.2 & 77.8 & 32.3 & 67.7 & 29.2 & 70.8 & 27 & 73 \\
\hline Private Context & 26.7 & 73.3 & 29.0 & 71.0 & 37.5 & 62.5 & 30 & 70 \\
\hline Nonprofit Context & 20.0 & 80.0 & 12.9 & 87.1 & 25.0 & 75.0 & 19 & 81 \\
\hline Religious Context & 6.7 & 93.3 & 16.1 & 83.9 & 4.2 & 95.8 & 9 & 91 \\
\hline Grassroots Context & 17.8 & 82.2 & 12.9 & 87.1 & 20.8 & 79.2 & 17 & 83 \\
\hline
\end{tabular}

The relevance of values-based leadership is summarized in Table 6. As evident from the responses in the total column, a consistent majority of responses rank values-based leadership as more relevant to all the work domains ranging from political to the community and grassroots contexts. One response set that stands out is that related to the religious work domain. An overwhelming majority of respondents saw values-based leadership as most relevant to the religious work arena. Caribbean Islands are highly religious and values-based leadership is considered very important. This sentiment is confirmed from findings by Lituchy et al., (2013). 
TABLE 7

RELEVANCE OF SPIRITUAL LEADERSHIP

\begin{tabular}{|l|l|l|l|l|l|l|l|l|}
\hline & \multicolumn{2}{|l|}{$\begin{array}{l}\text { Private Sector } \\
\text { Respondents }\end{array}$} & \multicolumn{2}{l|}{$\begin{array}{l}\text { Public Sector } \\
\text { Respondents }\end{array}$} & $\begin{array}{l}\text { NGO/Other } \\
\text { Sector } \\
\text { Respondents }\end{array}$ & Total \\
\hline $\begin{array}{l}\text { Leadership } \\
\text { within }\end{array}$ & Relevance & Relevance & \multicolumn{2}{l|}{ Relevance } & \multicolumn{2}{l|}{ Relevance } \\
\cline { 2 - 9 } & Less & More & Less & More & Less & More & Less & More \\
\hline Political Context & 62.2 & 37.8 & 51.6 & 48.4 & 50.0 & 50.0 & 56 & 44 \\
\hline Public Context & 57.8 & 42.2 & 48.4 & 51.6 & 62.5 & 37.5 & 56 & 44 \\
\hline Private Context & 62.2 & 37.8 & 51.6 & 48.4 & 54.2 & 45.8 & 57 & 43 \\
\hline Nonprofit Context & 44.4 & 55.6 & 35.5 & 64.5 & 50.0 & 50.0 & 43 & 57 \\
\hline Religious Context & 6.7 & 93.3 & 0 & 100 & 8.3 & 91.7 & 5 & 95 \\
\hline Grassroots Context & 33.3 & 66.7 & 12.9 & 87.1 & 33.3 & 66.7 & 27 & 73 \\
\hline
\end{tabular}

Table 7 contains the response summary for the relevance of spiritual leadership. The respondents across the three sectors were somewhat divided about how they saw the relevance of spiritual leadership to the political, public, and private context. Most of them found that it was less relevant to these work arenas. As expected, an overwhelming majority of respondents felt that spiritual leadership was more relevant to the religious work domain. A good degree of relevance was shown for this type of leadership for the community and grassroots settings as well.

TABLE 8

RELEVANCE OF LEADERSHIP THEORIES BY GENDER

\begin{tabular}{|c|c|c|c|c|c|c|c|c|c|c|c|c|}
\hline & \multicolumn{4}{|c|}{$\begin{array}{c}\text { Political Work } \\
\text { Context }\end{array}$} & \multicolumn{4}{|c|}{$\begin{array}{c}\text { Public Organizations } \\
\text { Context }\end{array}$} & \multicolumn{4}{|c|}{$\begin{array}{l}\text { Private Organizations } \\
\text { Context } \\
\end{array}$} \\
\hline \multirow[t]{2}{*}{$\begin{array}{l}\text { Leadership } \\
\text { Style }\end{array}$} & \multicolumn{2}{|c|}{$\begin{array}{l}\text { Female } \\
\text { Relevance }\end{array}$} & \multicolumn{2}{|c|}{$\begin{array}{l}\text { Male } \\
\text { Relevance }\end{array}$} & \multicolumn{2}{|c|}{$\begin{array}{l}\text { Female } \\
\text { Relevance }\end{array}$} & \multicolumn{2}{|c|}{$\begin{array}{l}\text { Male } \\
\text { Relevance }\end{array}$} & \multicolumn{2}{|c|}{$\begin{array}{l}\text { Female } \\
\text { Relevance }\end{array}$} & \multicolumn{2}{|c|}{$\begin{array}{l}\text { Male } \\
\text { Relevance }\end{array}$} \\
\hline & Less & More & Less & More & Less & More & Less & More & Less & More & Less & More \\
\hline Transform & 22.4 & 77.6 & 19.2 & 80.8 & 32.7 & 67.3 & 23.1 & 76.9 & 24.5 & 75.5 & 17.3 & 82.7 \\
\hline Authoritative & 24.5 & 75.5 & 30.8 & 69.2 & 26.5 & 73.5 & 30.8 & 69.2 & 40.8 & 59.2 & 38.5 & 61.5 \\
\hline Adaptive & 30.6 & 69.4 & 17.3 & 82.7 & 30.6 & 69.4 & 19.2 & 80.8 & 18.4 & 81.6 & 13.5 & 86.5 \\
\hline Servant & 36.7 & 63.3 & 36.5 & 63.5 & 38.8 & 61.2 & 46.2 & 53.8 & 53.1 & 46.9 & 55.8 & 44.2 \\
\hline Transactional & 55.1 & 44.9 & 46.2 & 53.8 & 44.9 & 55.1 & 40.4 & 59.6 & 44.9 & 55.1 & 21.2 & 78.8 \\
\hline $\begin{array}{l}\text { Values- } \\
\text { Based }\end{array}$ & 24.5 & 75.5 & 26.9 & 73.1 & 26.5 & 73.5 & 28.8 & 71.2 & 32.7 & 67.3 & 30.8 & 69.2 \\
\hline Spiritual & 53.1 & 46.9 & 61.5 & 38.5 & 57.1 & 42.9 & 57.7 & 42.3 & 53.1 & 46.9 & 63.5 & 36.5 \\
\hline
\end{tabular}


TABLE 9

RELEVANCE OF LEADERSHIP THEORIES BY GENDER

\begin{tabular}{|c|c|c|c|c|c|c|c|c|c|c|c|c|}
\hline \multirow{3}{*}{$\begin{array}{l}\text { Leadership } \\
\text { Style }\end{array}$} & \multicolumn{4}{|c|}{$\begin{array}{c}\text { NGO/Nonprofit } \\
\text { Organizations Context }\end{array}$} & \multicolumn{4}{|c|}{$\begin{array}{c}\text { Religious Institutions } \\
\text { Context } \\
\end{array}$} & \multicolumn{4}{|c|}{$\begin{array}{c}\text { Community/Grassroots } \\
\text { Work Context }\end{array}$} \\
\hline & \multicolumn{2}{|c|}{$\begin{array}{l}\text { Female } \\
\text { Relevance }\end{array}$} & \multicolumn{2}{|c|}{$\begin{array}{l}\text { Male } \\
\text { Relevance }\end{array}$} & \multicolumn{2}{|c|}{$\begin{array}{l}\text { Female } \\
\text { Relevance }\end{array}$} & \multicolumn{2}{|c|}{$\begin{array}{l}\text { Male } \\
\text { Relevance }\end{array}$} & \multicolumn{2}{|c|}{$\begin{array}{l}\text { Female } \\
\text { Relevance }\end{array}$} & \multicolumn{2}{|c|}{$\begin{array}{l}\text { Male } \\
\text { Relevance }\end{array}$} \\
\hline & Less & More & Less & More & Less & More & Less & More & Less & More & Less & More \\
\hline Transform & 28.6 & 71.4 & 13.5 & 86.5 & 12.2 & 87.8 & 13.5 & 86.5 & 18.4 & 81.6 & 11.5 & 88.5 \\
\hline Authoritative & 55.1 & 44.9 & 50.0 & 50.0 & 51.0 & 49.0 & 46.2 & 53.8 & 65.3 & 34.7 & 61.5 & 38.5 \\
\hline Adaptive & 12.2 & 87.8 & 19.2 & 80.8 & 30.6 & 69.4 & 34.6 & 65.4 & 28.6 & 71.4 & 13.5 & 86.5 \\
\hline Servant & 24.5 & 75.5 & 38.5 & 61.5 & 18.4 & 81.6 & 23.1 & 76.9 & 26.5 & 73.5 & 34.6 & 65.4 \\
\hline Transactional & 69.4 & 30.6 & 59.6 & 40.4 & 79.6 & 20.4 & 69.2 & 30.8 & 77.6 & 22.4 & 73.1 & 26.9 \\
\hline $\begin{array}{l}\text { Values- } \\
\text { Based }\end{array}$ & 16.3 & 83.7 & 21.2 & 78.8 & 8.2 & 91.8 & 9.6 & 90.4 & 16.3 & 83.7 & 17.3 & 82.7 \\
\hline Spiritual & 34.7 & 65.3 & 51.9 & 48.1 & 2.0 & 98.0 & 5.8 & 94.2 & 24.5 & 75.5 & 30.8 & 69.2 \\
\hline
\end{tabular}

Tables 8 and 9 above summarize the results related to how men and women see the relevance of leadership in the various work domains. In most cases, the variation between responses is not that stark. However, there are a few areas where we see some differences and emphases that men and women placed in terms of how they saw the relevance of leadership. For instance, a larger number of males saw transformational leadership's relevance to the NGO sector. Similarly, male respondents saw a stronger role for adaptive leadership within the political and public work domain as compared to their female counterparts. On the other hand, female respondents reported a stronger relevance for transactional leadership in the private sector as compared to their male peers. Male respondents also reported a stronger linkage between adaptive leadership and the community and grassroots work arenas. In terms of servant leadership, female respondents found it has stronger relevance to the private organizational context.

\section{CONCLUSION}

As we noted in the previous section, transformational leadership was considered highly relevant by the majority of the respondents across the six work domains. In some ways, this is not a surprising finding. Transformational leadership is a well-established theory of leadership which has been examined in a number of cross-cultural settings previously. Transactional leadership, on the other hand, was perceived relevant to the private sector by most of the respondents but not in a number of other work domains. This result is understandable because it is the individual's commitment to service which brings them to the NGO, religious, and community work domains. At the same time, the finding raises an interesting question about people's perceptions of the private sector. If the respondents perceive the private-sector organizations as primarily profit focused which is in itself a transaction relationship between these entities and the larger society, therefore they may expect the transactional leadership style to be more suitable in this work context as compared to other areas. Interestingly, the respondents also saw servant leadership as more relevant to the private sector in comparison to the other sectors. One explanation for this may be that servant leadership has been linked to the concept and practice of corporate social responsibility in the private sector for profit organizations. As such, respondents may see a role for this style along with the transformational and transactional leadership styles.

Values-Based leadership was rated as more relevant to a number of work domains but particularly to the religious context. Spiritual leadership style was rated as more related to the religious context and moderately related to the NGO and community work arenas. These perceptions are not surprising 
considering the expectations of service and sacrifice that are associated with these sectors. We believe our results offer important insights that may inform the leadership research and practice in the Caribbean region starting with more attention to the transformational leadership style.

As is the case with most research, there are some limitations and cautions that must be taken into consideration with our research. Firstly, our approach was etic in nature and focuses on the relevance of leadership theories developed abroad. A more emic approach may reveal the nature of leadership styles more indigenous to the region.

As noted above, our data came from three countries in the region and thus may not be fully generalizable of other countries which form the region. These limitations also present future research opportunities. Given the scope of our work, we are not able to cover some other important and emerging leadership theories such as relational or systems leadership theories. Similarly, there has been some recent attention to newer ideas such as cross-sector leadership which will need attention moving forward.

Overall, we feel that our work is an important step in addressing the empirical gap in leadership research in the Caribbean region as noted in the earlier sections of this paper. This study is also important because it created an opportunity to examine a number of important leadership theories in an integrative fashion. Finally, the findings provide significant implications for leadership practice and development. Specifically, an important finding is that transformational leadership approaches are seen as widely relevant in the Caribbean region and this may be an important consideration for leadership development programs. 


\section{REFERENCES}

Barbados' mucky election. (2018, May $26^{\text {th }}$ ). The Economist 201921. The Economist Group.

Bass, B. M., \& Steidlmeier, P. (1999). Ethics, character, and authentic transformational leadership behavior. Leadership Quarterly, 10(2), 181.

Beugre, C., \& Offodile, O. (2001). Managing for Organizational Effectiveness in Sub-Saharan Africa: A Culture-Fit Model. International Journal of Human Resource Management, 12(4), 535-550.

Caesar, C. (2013). Leading in context: A review of leadership styles to inform school effectiveness in small island states. European Journal of Sustainable Development, 2(1), 109-122.

Carrison, D. (2016). Transactional vs. transformational leadership. Industrial Management, 58(1), 6-6.

Carroll, A. B. (2005). Servant leadership: An ideal for nonprofit organizations. Nonprofit World, 23(3), $18,18-20$.

Corruption Perceptions Index. (2018). Transparency International Corruption Index, 2018. Berlin, Germany: Transparency International. Retrieved from https://www.transparency.org/cpi2018

Dinham, S., \& Scott, C. (2008). Responsive and demanding leadership. Synergy, 6(2), 19-21.

Fernández, J. E., \& Hogan, R. T. (2002). Values-based leadership. Journal for Quality \& Participation, 25(4), 25-27.

Flemming, P. (2016). Similarities and Differences between Public and Private Sector Leadership Strategies in the Caribbean: Empirical Findings on the Link between Leadership, Culture and Performance. Business and Management Studies, 2(4), 1-14.

Glover, J., Friedman, H., \& Jones, G. (2002). Adaptive leadership: When change is not enough (part one). Organization Development Journal, 20(2), 15, 15-32.

Groves, K., \& LaRocca, M. (2011). An empirical study of leader ethical values, transformational and transactional leadership, and follower attitudes toward corporate social responsibility. Journal of Business Ethics, 103(4), 511-528. doi:10.1007/s10551-011-0877-y

Goleman, D. (2000). Leadership that gets results. Harvard Business Review, 78(2), 78-90.

Heifetz, R. A., \& Laurie, D. L. (1997). The work of leadership. Harvard Business Review, 75(1), $124-$ 134.

Hirschy, J. (2008). Servant Leadership: A Case Study of Jamaican Link Ministries. Paper presented at the Servant Leadership Roundtable, May 2008. Published by the School of Global Leadership \& Entrepreneurship, Regent University.

Jago, A. (1982). Leadership Perspectives in Theory and Research. Cited in Lituchy, T., Ford, D., and Punnett, B.J. (2013). Leadership in Uganda, Barbados, Canada and the USA: Exploratory Perspectives. African Journal of Economic and Management Studies, 4(2), 201-222.

Jamaludin, Z., Rahman, N. M. N. A., Makhbul, Z. K. M., \& Idris, F. (2011). Do transactional, transformational and spiritual leadership styles distinct? A conceptual insight. Journal of Global Business \& Economics, 2(1), 73-85.

James, R. (2008). Leadership Development inside-Out in Africa. Nonprofit Management and Leadership, 18(3), 359-375.

Jit, R., Sharma, C., \& Kawatra, M. (2016). Servant leadership and conflict resolution: A qualitative study. International Journal of Conflict Management, 27(4), 591-612.

Kotter, J. (1988). The Leadership Factor. The Free Press: New York, NY.

Lituchy, T., Ford, D., \& Punnett, B.J. (2013). Leadership in Uganda, Barbados, Canada and the USA: Exploratory Perspectives. African Journal of Economic and Management Studies, 4(2), 201-222.

Lituchy, T., Galperin, B., \& Punnett, B.J. (2017). LEAD: Leadership Effectiveness in Africa and the African Diaspora. Palgrave: N.Y., N.Y.

Marshall, I. (2015a). Principal Leadership Style and Teacher Commitment Among a Sample of Secondary School Teachers in Barbados. Journal of Arts \& Humanities, 4(5), 43-58.

Marshall, I. (2015b). Principal Leadership Style and Teacher Stress Among a Sample of Secondary School Teachers in Barbados. Caribbean Educational Research Journal, 3(1), 76-90. 
McFarlin, D., Coster, E., \& Mogale-Pretorius, C. (1999). South African management development in the twenty-first century. Journal of Management Development, 18(1), 63-78. https://doi.org/10.1108/02621719910250474

Northouse, P. (2019). Leadership theory and practice (8th ed.). London, United Kingdom: Sage Publications.

Paglis, L., \& Green, S. (2002). Leadership Self-Efficacy and Managers Motivation for Leading Change. Journal of Organizational Behavior, 23(2), 215-235.

Paton, D. (2009). Obeah Acts: Producing and Policing the Boundaries of Religion in the Caribbean. Small Axe, 28(13), (No. 1), 1-18.

Pekerti, A. (2010). Servant leadership as antecedent of trust in organizations. Leadership \& Organization Development Journal, 31(7), 643-663.

Popper, M., \& Zakkai, E. (1994). Transactional, charismatic and transformational Leadership. Leadership \& Organization Development Journal, 15(6), 3-7.

Prilleltensky, I. (2000). Value-based leadership in organizations: Balancing values, interests, and power among citizens, workers, and leaders. Ethics \& Behavior, 10(2), 139-158.

Punnett, B.J., \& Greenidge, D. (2009). Cultural Mythology and Global Leadership in the Caribbean Islands, in Kessler, E. and Wong-Mingli, D. Cultural Mythology and Global Leadership. Edgar Elgar: Northampton, MA.

Rost, J. (1993). Leadership for the Twenty-first century. Westport, CT: Praeger Publishers.

Russell, R. (2001). The role of values in servant leadership. Leadership \& Organization Development Journal, 22(2), 76-84.

Shamir, B., House, R. J., \& Arthur, M. B. (1993). The motivational effects of charismatic leadership: A self-concept based theory. Organizational Science, 4, 577-594.

Smith, B. (2003). Worldview and Culture: Leadership in Sub-Sahara Africa. New England Journal of Public Policy, 19(1), 15, 243-274

Smith, P., Francis, D., \& Harper, A. (2015, September). Reframing transformational leadership for Education and Nation Building in the Caribbean. Caribbean Educational Research Journal, 3(2), 76-89

Sternberg, R. (2013). Leadership styles for academic administrators: What works when? Change, 45(5), 24-27.

Whittington, J. L., Coker, R. H., Goodwin, V. L., Ickes, W., \& Murray, B. (2009). Transactional Leadership Revisited: Self-Other Agreement and Its Consequences. Journal of Applied Social Psychology, 39(8), 1860-1886. 